\title{
PHYSIOLOGICAL ASPECTS OF FERTILIZATION AND HYBRIDIZATION IN FERNS ${ }^{I}$
}

\author{
W. D. Hoxt
}

(WITH TWELVE FIGURES)

The present investigation was undertaken as the first part of a study of the physiology of cell fusions. The first thing to be done in such a study is to determine what cells will fuse under normal conditions; the next step is to discover, in cases where fusions do not normally occur, the point in the events occurring in normal fusions where the process has stopped, and, so far as possible, the conditions causing the cessation of this process; the third step will be to discover conditions permitting the fusion of cells which will not fuse under normal conditions.

The results obtained in the present study will be considered under three heads: (I) under the heading Hybridization the evidence bearing on the occurrence of hybrids in ferns will be considered, and the results of many attempts to induce experimentally hybridization between many species and several genera will be given; (2) under the heading Fertilization it has been possible to show, in some of the cases where fusions have not been obtained, at what point in the progress of normal fertilization the process has stopped, and to indicate some of the factors determining this cessation; (3) under the heading Movements and reactions of sperms will be given the observations made to determine whether the reactions of fern sperms are of the same kind as those described for protozoa or whether they are of a different kind.

\section{A. Hybridization}

\section{HISTORICAL AND CRITICAL}

A fern hybrid was described as early as 1837 (29), when the nature of the spores and the prothallus were still unknown and the ideas concerning reproduction among pteridophytes were still shadowy.

x Contributions from the Botanical Laboratory of the Johns Hopkins University, No. I3. 
In this case two species, Gymnogramme chrysophylla and G. calomelanos, were growing near each other; spores of the former, when planted, produced ferns which were supposed to show characters approaching those of the other species. This case is described here because it shows a tendency which has persisted among students of ferns to the present day, that of describing as hybrids plants which are supposed to show intermediate characters, without sufficient evidence as to the real origin of these plants.

All later studies of fern hybrids fall into three groups. The first includes the numerous cases where plants have been found in the field or greenhouse differing in some respects from the characters considered as typical for one species, and supposedly approaching in these respects the characters considered as typical for another species. The second group includes those cases where spores, prothalli, or portions of prothalli of two or more species have been planted together in the hope that cross-fertilization might occur, and plants arising from these cultures showing supposedly intermediate characters have been described as hybrids. The third group is composed of a single case where sperms of a known species were presented to prothalli of another species bearing only archegonia, and the attempt was made to determine whether development of the embryo occurred or not.

The first group is represented by the works of LuERsSEN (28), Druery (I0, II), Miss Slosson (45), Hahne (I5), Dowell (8), BENEDICT $(\mathbf{I}, \mathbf{2})$, and others. Focke (I4) lists the supposed hybrids described before I88I, and concludes that, except in the genus Gymnogramme, all are doubtful. It is not evident why Focke excepts Gymnogramme in this conclusion.

The reasons for regarding the kind of evidence considered by these authors as sufficient to prove the hybrid nature of the supposed crosses are given by BENEDICT (2) in a recent paper. These reasons are (I) the intermediate character of the supposed hybrid, (2) its sterility, abnormality, and greater vigor as compared with the supposed parents, (3) its occurrence being found only occasionally and then usually with the supposed parents. BENEDICT states, however, that "irregular plants, which are to be explained as due to ecological conditions or as sports rather than as hybrids, are not unusual. The immediate 
presence of the parent species is not a necessity, since fern plants are often long-lived, and the greater vigor of the crosses might render them resistant to conditions sufficiently adverse to destroy the parent species." While many of the plants studied by BENEDICT and others may be hybrids, it would be extremely difficult to distinguish, in such cases, between "sports" and "hybrids," especially when the supposed parents are not present, and the conclusions founded on such evidence must always have a large element of uncertainty. Ferns, like other plants, are known to vary widely under different conditions, and certain tendencies toward variation are recognized by students of this group (31, p. 272).

The uncertainty of conclusions founded on a study of the sporophyte is emphasized by the work of SADEBECK $(40,4 \mathrm{I})$. This author, sowing spores of Asplenium adulterinum and of A. Serpentini on a serpentine-free substratum for successive generations, obtained respectively Asplenium viride and $A$. Adiantum nigrum, thus showing that forms previously described as species were but serpentine varieties. The first transformation to the non-serpentine form of the species occurred in the former case in the fourth, in the latter case in the fifth generation, the serpentine form being maintained for several generations on a serpentine-free substratum. Even cultures, therefore, unless continued for many generations under different conditions, may fail to show the real nature of a supposed species.

In discussions concerning hybridity, much weight is given to the point that in the characters in which the specimens differ from the "type of the species," they approach those of some other species. This may be due to hybridization as supposed, or it may be due to some other cause. The serpentine form of Asplenium viride (" $A$. adulterinum") assumes, in many respects, an intermediate form between the "typical" $A$. viride and $A$. trichomanes, showing that an ecological variety may assume a form approaching that of another species.

If species were clearly recognizable units with distinct limits, and if these units were changeable only by hybridization, we should be justified in describing intermediate forms as hybrids. But, considering the cases mentioned above and the variation that is known to 
occur in all groups, this kind of evidence seems entirely inadequate to prove the hybrid nature of any individual. While, if all the three lines of evidence given above concurred in indicating any single form as a hybrid, they would furnish some reason for so regarding it, but they would not furnish conclusive proof of its hybridity. This proof could be obtained only by producing experimentally the form in question from a cross between cells of known parentage.

The second class of evidence is given in the works of Druery (9), Farmer (12), Lowe (27), Miss Slosson (46, 47), Hans (16, I7), and others. The supposed hybrids described by these authors were obtained by planting together spores, prothalli, or parts of prothalli of different species and trusting to chance to obtain a cross. Some of the resulting offspring were adjudged hybrids because of their apparently intermediate character between their supposed parents. This evidence, while more trustworthy than that considered above, is not beyond question. Lowe obtained such various results from his sowings of mixed spores that he was led to propose the theory of "multiple parentage" to account for all the differences in the offspring. MAXON (30) lists the three authentic cases of hybridization between species as the Phyllitis scolopendrium (Scolopendrium vulgare) $\times$ Ceterarch officinarum described by DRUERY (IO, II), the Polypodium vulgare elegantissimum $\times$ Phlebodium aureum described by FARMER (I2), and the Polystichum aculeatum $\times$ Polystichum angulare described by Lowe (27) and DRUERY (II).

DAVENPORT (6) considers the last two cases uncertain and expresses no opinion about the first case. He concludes (p. 7): "I do not see how we can ever obtain absolute proof of hybridity in nature, because it is manifestly impossible for us to observe the process through which it is brought about; nor do I see how we can obtain positive proof through mixed sowing, as it is equally impossible for us to determine from which species the germinating spores come. It seems to me that in all such cases there will always be an element of uncertainty that will compel us to rely altogether upon inductive reasoning for our conclusions, which are not always likely to be safe."

The best work in this line is that of Miss Slosson $(46,47)$. By planting together portions of the prothalli of the supposed parents, she obtained offspring resembling the plants previously described 
as hybrids, Dryopteris cristata $\times D$. marginalis and Asplenium platyneuron $\times$ Camptosorus rhizophyllus (the well-known Asplenium ebenoides). These results are almost convincing, but do not place the subject beyond question. Cutting does not, in every case, separate the antheridia and archegonia; then, too, the prothalli formed branches and produced new sexual organs, so that, in the case of Asplenium platyneuron and Camptosorus rhizophyllus, many plants of each species appeared together with a few of the supposed hybrids. These experiments, therefore, are open to the objection raised by Miss SLosson (46) herself against the method of planting spores or whole prothalli together. They prove that the offspring come from one of the species planted, but do not prove whether this is by hybridization or some other method of variation. So far as the author is aware, no experiments have been made to prove that Asplenium platyneuron may not at times give rise to Asplenium ebenoides. Specimens of Asplenium pinnatifidum observed by COPELAND (5) approached, in their variable characters, Camptosorus rhizophyllus and bore a striking resemblance to Asplenium ebenoides, although no Camptosorus was found in the immediate neighborhood.

DRUERY (9) observed variation in plants of Crytomium falcatum and Lastrea pseudo-mas cristata produced apogamously. In another experiment he obtained from spores of a single plant of Athyrium plumosum offspring showing almost as many differences in the leaves as were found by Lowe in his "plants with multiple parentage."

In a recent article LEAviTT (23) has described the origin, through vegetative variation, of the Pierson and Whitman ferns, and has described the particular type of variation called "homoeosis" in ten species of wild ferns distributed among six genera.

It is clear that other means than hybridization may produce variations among ferns, and that some of these variations may give characters approaching those which are supposed to belong to other species. This being the case, we must regard as unproved all cases of supposed hybridization founded on structural characters of the sporophyte.

In the third class of evidence mentioned comes the work of VOEGLER (5I). This is the one case of experimental studies on hybridization in ferns where the experimenter attempted to work with known units; 
it is, therefore, the only case where the results are trustworthy. VOEGLER presented the sperms of several species to the archegonia of other species and attempted to determine, by observing the living sperms after their entrance into the archegonium, whether they fused with the egg or not. The following combinations were tried: Dicksonia antarctica $+\times N e$ phrolepis davalloides $\hat{\delta}$; Ceratopteris thalictroides $¥$ or Nephrolepis davalloides $\$ \times$ Dicksonia antarcticas, or

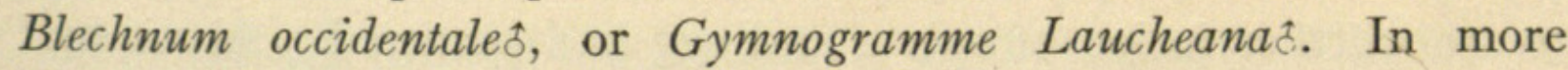
than roo cases of entrance, no fusion of the sperm with the egg was observed. VoEgler also presented the sperm of several species to the prothalli of other species bearing only archegonia, and, having replanted these, examined them after one or two days to determine by the appearance of the archegonia whether development of the egg had begun or not. In all cases negative results were obtained; the archegonia had turned brown.

There are obvious objections to the methods used: (I) there were not sufficient precautions to insure the absence of sperms on the archegonial prothalli; (2) observations on the surface can scarcely give certain conclusions about the fusion of sperm with the egg; (3) reliance is placed on the appearance of the archegonia after one or two days to determine whether development of the egg has occurred or not. Since in the two species where the time has been noted (SHAw 42, ConARD 4) the first division of the egg does not occur until after seven days, and since in this investigation the same time has been found to hold for other species, the method used does not seem beyond question.

In this work of VoEGLER's, the most reliable study of hybridization in ferns, all the results are negative. The author concludes that while hybridization is not thereby disproved, this must seldom occur and then only between certain species.

\section{METHODS}

Since the value of all work of this sort depends on knowing with certainty the origin of the sexual cells brought together in the archegonium, it will be well to describe in some detail the methods used for insuring this in the present investigation.

The prothalli used were in every case raised from spores. The 
determination of every species used was made or verified by Mr. W. R. Maxon: Antheridial prothalli were placed in water on a slide, and prothalli bearing only archegonia of the species necessary to make the desired cross were added to these; the entrance of sperms into the archegonia was then followed under the microscope. After being left on the slide for one to four hours, the prothalli were either planted on soil in separate pots or were fixed and studied in section to see whether fusion of sperm and egg had occurred. About half of the prothalli in which experimental fertilization was attempted were planted and the other half sectioned.

In this method there are four places where an error is especially likely to occur: (I) in gathering the spores of several species in one day, these may become mixed; (2) in planting the spores, or after these are sown, spores of other species may fall into the pot and contaminate the culture; (3) fertilization may have taken place before the prothalli are removed from the pot for the experiment; (4) the female prothalli may bear antheridia.

All these dangers were especially guarded against. In collecting spores, mature fronds were chosen, and being shaken as little as possible were carefully wrapped in several thicknesses of paper. The fruiting portions of the fronds were touched as little as possible, and the hands were washed or carefully wiped with a damp cloth between each collection.

The spores were sown on soil which was sterilized by heating to $150^{\circ} \mathrm{C}$. for six to twenty-four hours. All sowings were made in rooms in which no other ferns were ever kept. When more than one sowing was made on any day, these were made in widely separated parts of the rooms, and after each sowing all the surrounding furniture and walls were wiped with a wet cloth. Before and after each sowing the hands were carefully washed and all instruments used were sterilized by boiling. The pots were kept in the laboratory where no other ferns were grown, or in the greenhouse. In this room of the greenhouse there were three fruiting specimens of ferns, but these were on the opposite side of the room. The cultures were covered with glass. In spite of these precautions, a small amount of moss appeared in several of the pots, and fungi occasionally made their entrance. It is not believed that the cultures were contaminated by 
fern spores, however, because more than roo young sporophytes from the different pots were obtained and raised to a distinguishable age, and all were of the species which was planted in the pot from which they came.

In order to prevent the occurrence of fertilizations in the pots, all cultures were watered very sparingly and only from below-by pouring water into the saucers. The soil and air were kept just moist enough to keep the prothalli in good condition. The soil was not allowed to become wet and no water was allowed to collect on the glass. In spite of these precautions, many fertilizations took place in some of the pots. Except in one case noted, however, no culture was used for archegonia unless it was free from sporelings for at least a week before and two weeks after the experiment.

In most cases the prothalli used for archegonia were examined under the microscope before being placed in water, and any portions of the prothalli bearing antheridia were cut off, and all adherent male prothalli were removed. In some cases the prothalli were not examined dry, but were placed directly in water. Antheridia or male prothalli, if present, were removed before escape of the sperms had occurred. All such cases were recorded, and no female prothallus was used for crossing if there was any reason to believe that sperms of its own species were present. By these means it was possible to be fairly sure that no antheridia of the species to be used as female were present; sometimes, however, antheridia were overlooked. In cases where the prothalli were fixed, therefore, the entire prothallus was sectioned and every section was examined for antheridia. Over I50 prothalli were thus sectioned and examined, and among these, antheridia were found in only two cases where they had not been detected by the previous examination. This method, therefore, seems to be a satisfactory one.

From the fact that the above methods were carrried out faithfully, the conclusion seems warranted that, in this work, we are dealing with sperms and eggs of known parentage.

\section{RESULTS}

Abundant entrance of sperms has occurred into archegonia of the same species and of different species. When the sperm and egg were 
of the same species, many fusions were obtained; but in not a single case among the combinations tried was fusion obtained between an egg and a sperm of different species, in spite of the fact that sperms were in a few cases observed in contact with the egg.

The results of this portion of the investigation are shown in the following tables. In the first table are given the results of the experiments where the prothalli were sectioned and examined for fusions; in the second table are given the results of the experiments where the prothalli were replanted on soil in the effort to obtain sporelings.

In the first table only those cases are included in which sperms were observed, in the sections, within the venters; in several other cases sperms were found in the necks of the archegonia, but not in contact with the egg. Not every entrance means the possibility of fusion, since entrance often occurs in archegonia whose eggs are bad and even in empty archegonia. It is impossible, however, to tell with certainty from sections whether an egg is good or bad. In order to eliminate the error of personal judgment, entrances have been counted in all cases where the venter contained an egg, regardless of whether this egg was good or bad. It was very evident in many

TABLE OF RESULTS OBTAINED FROM SECTIONS

\begin{tabular}{|c|c|c|c|c|}
\hline \& & & $\begin{array}{l}\text { Number of } \\
\text { prothalli }\end{array}$ & $\begin{array}{l}\text { Number of } \\
\text { entrances }\end{array}$ & $\begin{array}{c}\text { Number of } \\
\text { fusions }\end{array}$ \\
\hline 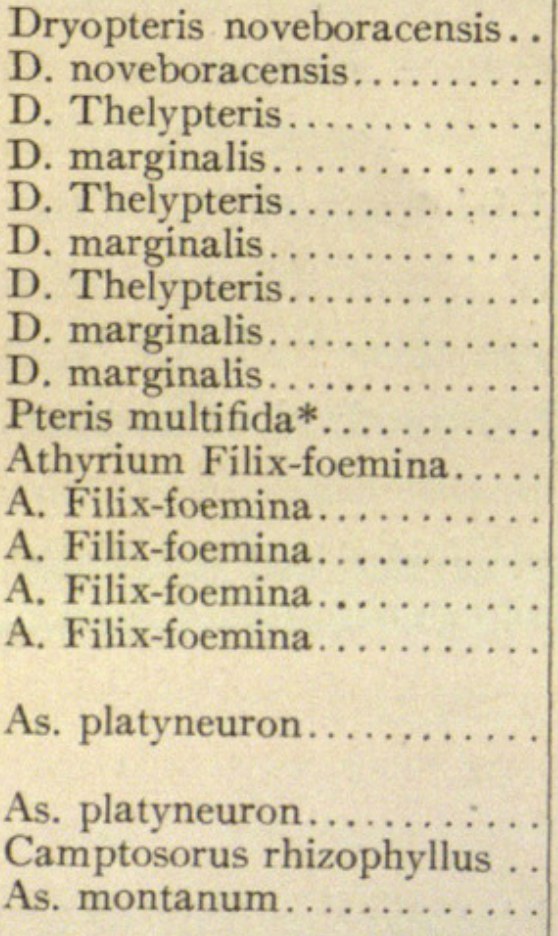 & $\begin{array}{l}\text { D. noveboracensis } \\
\text { D. Thelypteris } \\
\text { D. noveboracensis } \\
\text { D. marginalis } \\
\text { D. Thelypteris } \\
\text { D. Thelypteris } \\
\text { D. marginalis } \\
\text { D. noveboracensis } \\
\text { Pteris multifida } \\
\text { P. multifida } \\
\text { P. multifida } \\
\text { A. Filix-foemina } \\
\text { Asplenium montanum } \\
\text { As. platyneuron } \\
\text { As. platyneuron and } \\
\text { A. Filix-foemina } \\
\text { A. Filix-foemina and } \\
\text { As. platyneuron } \\
\text { Camp. rhizophyllus } \\
\text { As. platyneuron } \\
\text { As. Bradleyi }\end{array}$ & $\begin{array}{r}6 \\
8 \\
1 \\
5 \\
1 \\
4 \\
5 \\
16 \\
8 \\
4 \mathrm{I} \\
14 \\
6 \\
5 \\
11 \\
\\
2 \\
\\
2 \\
2 \\
4 \\
28\end{array}$ & $\begin{array}{r}10 \\
67 \\
1 \\
0 \\
0 \\
1 \\
1 \\
5 \\
9 \\
78 \\
15 \\
9 \\
6 \\
17 \\
\\
9 \\
1 \\
1 \\
1 \\
4 \\
2\end{array}$ & $\begin{array}{r}7 \\
0 \\
0 \\
0 \\
0 \\
0 \\
0 \\
0 \\
0 \\
26 \\
0 \\
4 \\
0 \\
0 \\
1 \\
1 \\
0 \\
0 \\
0 \\
0\end{array}$ \\
\hline
\end{tabular}


TABLE OF RESULTS OBTAINED FROM PROTHALLI REPLANTED ON SOIL

\begin{tabular}{|c|c|c|c|c|}
\hline \& & $\hat{o}$ & $\begin{array}{l}\text { Number of } \\
\text { prothalli }\end{array}$ & $\begin{array}{l}\text { Number of } \\
\text { entrances }\end{array}$ & $\begin{array}{l}\text { Number of } \\
\text { sporelings }\end{array}$ \\
\hline 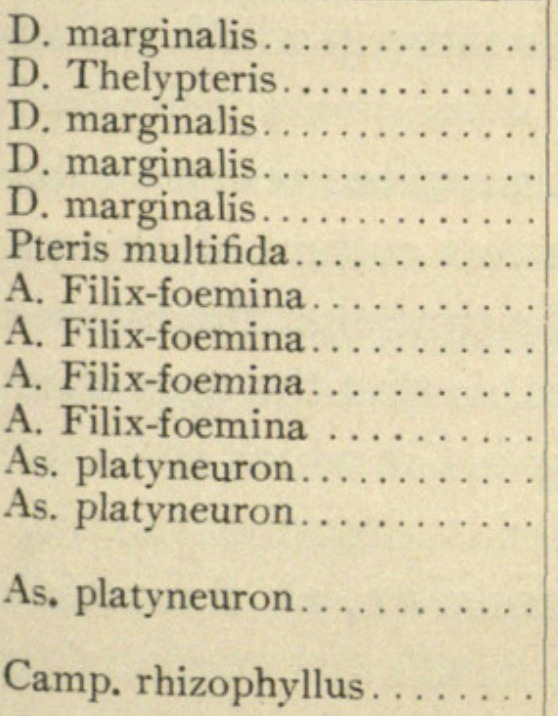 & $\begin{array}{l}\text { D. marginalis } \\
\text { D. Thelypteris } \\
\text { D. Thelypteris } \\
\text { D. noveboracensis } \\
\text { Pteris multifida } \\
\text { P. multifida } \\
\text { P. multifida } \\
\text { A. Filix-foemina } \\
\text { As. montanum } \\
\text { As. platyneuron } \\
\text { As. platyneuron } \\
\text { A. Filix-foemina and } \\
\text { As. platyneuron } \\
\text { Camp. rhizophyllus } \\
\text { and As. platyneuron } \\
\text { As. platyneuron }\end{array}$ & $\begin{array}{r}6 \\
5 \\
23 \\
1 \\
10 \\
24 \\
3 \\
43 \\
3 \\
8 \\
40 \\
\\
2 \\
\\
1\end{array}$ & $\begin{array}{c}0 \\
0 \\
0 \\
3 \\
0 \\
24 \\
10 \\
36 \\
0 \\
10 \\
? \\
6 \\
1 \\
6 ?\end{array}$ & $\begin{array}{l}0 \\
0 \\
0 \\
0 \\
0 \\
5 \\
0 \\
6 \\
0 \\
0 \\
6 \\
2 * \\
2 \\
0 \\
0\end{array}$ \\
\hline
\end{tabular}

*As. platyneuron.

of the entrances counted that the egg was bad, but the egg is no more likely to be bad in the cases of the entrance of a foreign sperm than in the cases of the entrance of its own sperm. It is believed, therefore, that the proportion of entrances in which fusions have been obtained may be compared in the two cases.

In the second table, the number of entrances obtained can only be approximated, since on the one hand not every entrance is observed, and on the other hand an observed entrance does not necessarily mean that the sperms have reached the venter.

These results for most of the combinations tried are not conclusive, but taken all together they constitute a considerable mass of evidence against the occurrence of hybridization in these ferns. Entrance of sperms of its own species into 97 archegonia on 59 prothalli, as shown in sections, gave 37 fusions; while the entrance of sperms of other species into I 29 archegonia on II I prothalli failed to give a single fusion.

The results obtained from replanting the prothalli on soil confirm those obtained from sections; all point against the occurrence of hybrids among these ferns.

The most noteworthy cases observed in sections are the following: Sixty-seven entrances of the sperms of Dryopteris Thelypteris into the 
archegonia of $D$. noveboracensis gave no fusions; while ten entrances of its own sperms into the archegonia of $D$. noveboracensis gave seven fusions.

It should be stated that most of these 67 eggs looked bad. Some, however, seemed good and appeared to be in the stage in which fusion would have been expected to occur if sperms of its own species had been present. Young archegonia in various stages were present on the prothalli sectioned, and sporelings appeared in this culture of Dryopteris noveboracensis before, during, and after the time that the experiments were made, so that it seems very improbable that the eggs were bad at the time of entrance in all the 67 archegonia in which entrance was obtained. In view of the supposed hybrids described among Dryopteris species by Dowell $(\mathbf{8})$ and BenEdict $(\mathbf{I}, \mathbf{2})$, this result is of considerable interest.

Using Athyrium Filix-foemina as the female parent, the entrance of the sperms of Pteris multifida into fifteen archegonia, and of the sperms of Asplenium montanum into the six archegonia, and of the sperms of Asplenium platyneuron into seventeen archegonia gave no fusions, while the entrance of its own sperms into nine archegonia gave four fusions.

In one attempted cross of Asplenium platyneuron sperms with Athyrium Filix-foemina eggs, antheridia of $A$. Filix-foemina also were present. In this case nine entrances were obtained and one fusion resulted. In the attempted reciprocal cross of Athyrium Filixfoemina sperms with Asplenium platyneuron eggs, sperms of Asplenium platyneuron were present; six entrances and two sporelings of Asplenium platyneuron were obtained. Evidently when sperms of two species are present, fusion may still take place between the egg and sperm of its own species; the presence of foreign sperms does not prevent this fusion.

As these experiments were made at the same time as the attempted crosses between the eggs of Athyrium Filix-foemina and the sperms of Asplenium platyneuron, they show that the failure to obtain fusions in that case was not due to a bad condition of the eggs or sperms.

The results given above do not disprove the existence of hybrids or the possibility of obtaining them. Owing to lack of material and to various accidents during the investigation, experiments were not made 
on a sufficient number of closely related species, and the results in most cases are not sufficiently conclusive to settle the question. But these experiments do show that not every combination of egg and sperm will yield a hybrid. Such a result is to be expected, but in view of the supposed cross between Camptosorus rhizophyllus and Asplenium platyneuron, it cannot be assumed without proof. A priori, we should expect hybrids to occur in some cases, but the fact remains that in the two investigations on the subject where known elements have been used, only negative results have been obtained.

\section{B. Fertilization}

It is well known that fusion will occur between the sexual cells of different species in some cases and will not occur in others, but few attempts have been made to determine in the cases where fusion does not occur the point at which the processes stop and the conditions causing this cessation, or to induce fusion in cases where it does not occur under normal conditions.

In ferns the process of normal fertilization has been described by Strasburger (48), Shaw (42), Voegler (5I), Thom (50), Mottier (34), Conard (4), and Yamanouchi (53). Pfeffer (36) and Voegler (5I) obtained entrance of the sperms of one species into the venters of other species in every combination tried. VOEGLER attempted to follow in more than roo living prothalli the movements of sperms which had entered the venters of other species. In every case, although the sperms came into contact with the eggs, they were unable to enter, and finally ceased their movements, or after several attempts to enter the egg left the archegonium. Presumably the phenomena observed were the same as those described below.

In the present investigation attraction of the sperms and their entrance into the venter has been obtained in every combination used, and in several cases the living sperms have been observed and their movements followed within the venters of the same species and of different species. In most cases the sperms were seen as an actively moving mass lying against the egg on the side turned toward the archegonial neck, the so-called receptive spot. The egg looked round and turgid. The individual sperms, when distinguished, had their anterior ends apparently in contact with the egg and were lashing 
about vigorously and revolving on their axes. Sometimes no locomotion was observed, the entire mass of sperms appearing to remain at the receptive spot, but often some of the sperms were observed to change their places and occasionally to leave the venter. In one case five sperms of Athyrium Filix-foemina were observed within an archegonium of the same species. All of these swam about within the venter and were observed to leave and reenter the venter several times. This prothallus when replanted on soil gave no embryo; the egg, therefore, was probably bad. In every case when sperms were observed within the venter and fusion resulted, the mass of sperms was observed to remain in contact with the egg. Perhaps a good egg attracts the sperms, while a bad egg does not.

Since in the cases mentioned the sperms were observed to bore against the receptive spot of the egg of another species as vigorously as they bored against the egg of their own species, it seems that the failure of such sperms to penetrate the egg is not due to any failure of the sperm to perform its part in the process. The failure of such sperms to enter the egg seems to be due either to some hindrance on the part of the egg or to some interaction of egg and sperm. There is little evidence to help us to decide between these two possibilities.

VOEGLER observed that, after the entrance of one sperm, a second sperm, although boring against the egg, was unable to enter. This would appear to be due to some change occurring within the egg, perhaps comparable to the formation of a membrane in the fertilized animal egg.

FARMER (I3) suggests that the entrance of more than one sperm into the egg is prevented by the occurrence of chemical changes in the cytoplasm of the egg immediately upon fertilization. He believes that these chemical changes produce substances which are injurious to the sperms, and presents some evidence for such an occurrence in the alga Halidrys. The entrance of a second sperm is not, however, always prevented. MotTIER (34) has figured two sperms within one egg of Onoclea Struthiopteris, and WoODBURN (52) has described two remarkable cases of polyspermy in the same species; in one of these, seven sperms were observed within the egg nucleus. Whether similar phenomena may occur in other species is not known.

MoRgan $\left(3^{2}, 33\right)$ has shown that in the ascidian Ciona, the sperms 
are practically incapable of fertilizing the eggs of the same individual and of certain other individuals, and has suggested that this is due to substances present in the egg furnishing a sort of "immunity" against these sperms.

Newman (35) was able, by treating the eggs of Fundulus with solutions of salts that precipitate colloids and increase the surface tension, to destroy the permeability of the egg membrane to the sperm, and then, by treating such eggs with solutions of salts that dissolve precipitated colloids and decrease surface tension, to restore the permeability of the membrane. The results of MORGAN on Ciona, according to this author, are capable of being explained by the assumption that different eggs and sperms have different relative surface tensions. NEWMAN states that "these experiments and those of LOEB and MORGAN seem to indicate that the relative surface tension of the egg and of the sperm is one important factor governing fertilization."

MoEnkhaus, however, in cross-fertilizing fishes that in many cases belong to widely separated orders, often found the percentage of eggs impregnated to be as great as in the check experiments where the sperm and eggs were of the same species. When eggs of Fundulus heteroclitus were subjected to a mixture of equal parts of sperms of the same species and of sperms of Menidia notata or M. gracilis, there were often more fertilizations by the foreign sperms than by the sperms of Fundulus. The foreign sperms were prepotent. MoenkHaus concluded that, among the forms used in the experiments, there is no specific adaptation such as chemical affinity, surface tension, etc., but that the prepotency of the foreign sperm is due to its being more active and hence a swifter fertilizer.

TENnENT (49) was unable to obtain crosses between different genera of echinoderms when the sperms were added to the eggs immediately after their removal from the ovary, but obtained fusion in every combination tried when the eggs had been allowed to stand for several hours. The time after removal from the ovary when fertilization with foreign sperms can be obtained is definite for any particular combination and is different in different combinations; it appears to depend on the species of sperm as well as on the egg employed. The eggs, after standing and becoming capable of fertilization by 
foreign sperms, are still able to be fertilized by their own sperms. Apparently changes take place progressively in the egg after its removal from the ovary, so that at different times it is capable of being fertilized by different species of foreign sperms, but these changes do not prevent the entrance of its own sperms. In a paper soon to be published, TenNent considers the effect of variation in the concentration of $\mathrm{OH}$ ions in the sea water in which the eggs stand before and during fertilization, and suggests that the variation in alkalinity brought about by artificial means in the experiments may imitate a natural seasonal variation in the concentration of the $\mathrm{OH}$ ions in ordinary sea water.

In crossing the eggs of the starfish Asterias ochracea with the sperms of the sea urchins Stronglyocentrotus purpuratus and $S$. franciscanus, LоEB (26) found that in sea water the sperms would fuse with the eggs of their own species, but not with those of the starfish; while in sea water made slightly alkaline, the sperms would unite with the eggs of the starfish, but not with those of their own species.

The failure of fern sperms to fuse with eggs of their own species which are just past maturity seems to be due, in part, to the physical condition of these eggs. Eggs which are evidently good have clear, soft-looking surfaces; while eggs as they become bad have darker surfaces that resemble more and more the appearance of a dried colloid. While it may be safely assumed that chemical changes are taking place within the egg at the same time, these physical changes would alone probably be sufficient to prevent the entrance of sperms.

We have no evidence to help us to decide whether a similar explanation would account for the failure of a second sperm to enter an egg of its own species, since no constant difference between fertilized and unfertilized eggs was detected. An attempt to apply the same explanation to the lack of fusion of foreign sperms meets with still greater difficulties. A careful scrutiny failed to show that eggs of other species, which as mentioned were not entered by sperms, had thicker membranes than did the eggs of their own species. If such a structure were present, we should find eggs of other species with thinner membranes than those of their own species, and should 
be able to obtain entrance of sperms into them; but no such case has been observed.

It is well known that different degrees of fusion of egg and sperm are obtained in different combinations. In some cases apparent fusion occurs, but the offspring remain sterile; in others a partial fusion occurs, but the offspring fail to develop; while in others no fusion occurs. A good discussion of the cases where after fusion the offspring remain sterile or undeveloped is given by DEVRIES (7). Such cases seem to be due to some interrelation of the chromatin content of the two sexual cells. The failure of egg and sperm to fuse seems to be caused by some physical or chemical interaction between the two. It remains to be seen whether there is any sharp line between these two classes of phenomena.

The possibility of fusion seems to be determined by different factors in different species of plants and animals. In some fish there is no specific adaptation; in echinoderms changes occurring after the removal of the eggs from the ovary permit the fusion of sperms of different species at different intervals of time; in some echinoderms the alkalinity of the sea water determines the possibility of the fusion of certain sperms; in some cases the relative surface tension of egg and sperm may determine the possibility of fusion; in other cases the presence of certain substances in the egg may prevent the fusion of certain sperms; and lastly double fertilization may be prevented by the formation of certain substances or by physical changes in the egg. The possibility of fusion seems, then, to be determined in some cases chiefly by physical, in others by chemical conditions.

In ferns we have no evidence of the existence of any physical barrier in the ripe egg that might prevent the entrance of foreign sperms. In the present state of knowledge, it seems probable that the failure of egg and sperm to fuse is due to some interaction between the two. It is greatly to be hoped that we shall some day be able to obtain crosses. We may then be able to obtain some evidence concerning the nature of this interaction.

\section{Movements and reactions of sperms}

The accounts of the movements of motile organisms may in general be considered in two groups. In the first of these, the 
positive response of an organism to a stimulus is as follows: the organism, swimming about at random and coming to that portion of the medium in which the stimulant is present, has its movements directly modified by the stimulating agent, so that the direction of its axis is turned toward the region of stimulation; it then proceeds in a straight line toward the stimulus. This is the "local action theory of tropisms" discussed by JennINGs (I 8, I9), and includes the "strophic" movements of RotherT (39) and the "topotactic" movements of Pfeffer (38). According to the other view, the organism, coming into the region of a stimulant to which it reacts "positively," enters this region without reacting, but upon tending to leave the region, it reacts by turning back; the "positive" response is thus obtained by a series of "negative" reactions whenever the organism tends to go in a direction leading away from the source of stimulation. This is the reaction described by JennINGS $(\mathbf{I} 8, \mathbf{1 9})$ for many protozoa and bacteria, and includes the "apobatic" movements of Rothert, and the "phobotactic" movements of PfEFfER. Similar explanations to those accounting for the positive reactions in the two views are given for negative reactions.

According to the former account, the source of stimulation is the unequal distribution of the stimulant on different parts of the organism; this acts locally on the organism, directly influencing the motor organs; and the essential part of the reaction is the orientation of the organism so that its axis is placed parallel to the direction of greatest stimulation. According to the latter account, the source of stimulation is the change of the conditions to which the organism is subjected; this change acts on the organism as a whole; and the essential nature of the reaction is that the organism shows no response in passing toward the optimum, but reacts by turning back upon tending to pass from the optimum.

The reaction of motile plant cells to chemical stimuli has been studied by Pfeffer $(36,37)$ in ferns, Marsilia, Selaginella, mosses, liverworts, Chara, bacteria, the swarmspores of Saprolegnia, and certain flagellates; by LiDforss $(\mathbf{2 4}, \mathbf{2 5})$ in Marchantia and Equisetum; by Shibata $(43,44)$ in Salvinia and Isoetes; by Voegler (5I) and Buller (3) in ferns; and by Rothert (39), KnIEP (22), and Jennings and Crosby (20) in bacteria. 
PfEFFER $(38$, p. 757$)$ suggests that, in rapidly reacting swarmcells, the positive, apparently "topotactic," response may be the result of a series of negative responses as is outlined above, but considers the reactions of many flagellates, the swarmspores of many algae, the sperms of ferns, and the swarmspores of Saprolegnia to be accomplished by tropistic orientation, "durch die typische tropistische Richtung der Körperachse" (38, p. 754). ${ }^{2}$ The same view is held by LIDForss for the movements of the sperms of Marchantia and Equisetum. Shibata explained the positive reactions of Isoetes sperms in the same manner, but considered certain negative reactions shown by them to be phobotactic, believing that both kinds of reaction exist in the same organism. The same possibility is suggested by LIDFORSS for the sperms of Marchantia. VOEgLER and BULLER do not discuss the nature of the reaction. RoTHERT showed that certain bacteria react only in tending to pass from the optimum in the manner outlined above; they thus finally collect in the region of optimum stimulation.

JENNINGS (18) has shown that the reactions of many of the lower organisms consist of a series of random movements performed when the organism tends to pass from the optimum, with the continuance of such of these movements as take it toward the optimum. The movements leading toward the optimum may in Stentor and other organisms be performed more readily after repetition, and in some organisms the final response-toward the region of optimal stimulation-may be attained with practically no random movements, thus giving a directive reaction. The difference between this type of reaction and that favored by the holders of the other view mentioned is, that in this one it is held that the stimulant acts on the organism as a whole and that the organism responds as a whole, performing complex and coordinated movements; in the other it is held that the stimulant acts on certain parts of the organism, directly modifying the action of these parts. According to Jennings, the reaction obtained depends on the physiological condition of the organism, which is in turn partly determined by the past experiences of the organism.

${ }^{2}$ The reference to the German edition is given here because of the abridgment of the English translation at this point. 
The positive response of fern sperms to the archegonium and to the salts of malic acid is too well known to need description. This is believed by most authors to be due to the directive action of the stimulating substance on the motor organs, the axis being thus turned toward the stimulant. Most workers, however, while holding this view, have noted that many sperms do not react as thus described, but may wander about the field, or pass through it indifferently, or may avoid it. Such reactions have been ascribed to individual differences.

Thus Jost (2I, p. 542) states that "whenever they (the sperms) come into the neighborhood of an archegonium, they twist sharply round, so as to direct their anterior ends toward the mouth of the archegonium; they thus rapidly approach it, enter its neck, and fuse with the ovum in the interior." In describing experiments with malic acid, Jost states (2 I, p. 542): "It may be clearly seen that the sperms curve around sharply the moment they come within the sphere of influence of the malic acid diffusing out of the tube, and place their long axes parallel with the course of the diffusion current. Without any acceleration of their movements they then steer their way toward the more concentrated solution straight for the mouth of the tube. Since the sperms distribute themselves equally in a homogeneous solution of malic acid, just as they do in water, we are bound to regard the unequal distribution of the acid as the directive stimulus."

The question before us is: Are the movements of fern sperms best explained as being due to the local action of different concentrations of a stimulant on different parts of the body, thus producing movements leading to an orientation of the axis; or are they to be regarded as the result of the action of the stimulant on the organism as a whole, the resulting movements being such as to take the organism toward the region of optimal concentration?

In the present investigation a few observations were made on the reactions of sperms to malic acid in capillary tubes, but most of the results on positive responses were obtained from the reaction of the sperms to the substance extruded from the archegonia of either the same or of different species. In such cases the prothalli bearing the antheridia and the archegonia were rinsed and placed in water 
on the slide under a cover glass, and the movements of the sperms followed. For other experiments the antheridial prothalli, after being rinsed, were placed in a few drops of water; and the sperms, after their escape, were transferred to the slide with a pipette. Since the sperms are too small to be studied with a binocular microscope, most of the observations were made with an ordinary microscope, using a Zeiss $8^{\mathrm{mm}}$ objective. The results given are based on the observation of thousands of sperms; they will, of course, not apply to every sperm whose movements were followed, but will apply only as a kind of average, stating in general the manner of reaction observed.

Most of the observations were made on the sperms of Pteris multifida, ${ }^{3}$ but these results were verified with the sperm of every species studied. The structure of the sperms is that of a flat, spirally coiled band bearing numerous cilia, especially near their anterior ends. Some of them are coiled to the left, others to the right; some of them appear to revolve clockwise, others in a counter-clockwise direction, and some of them seem at times to change their direction of rotation.

In water the sperms swim by rapid movements of their cilia, at the same time rotating on their axes and swinging their anterior ends through small circles. The result of this is that they progress in narrow spirals; their course in water approaches a straight line, but has occasional turnings. When the sperms are placed in quince seed jelly or a solution of India ink, however, their movements are strikingly different from those shown in water. They now swing their anterior ends through large circles, so that they proceed along wide spirals; they no longer pursue a course approaching a straight line, but turn here and there again and again. In thick ink they pass through spirals larger than those made in thin ink. Fig. I shows the differences in the spiral courses of sperms in thick ink, in thin ink, and in water. When they change the direction of movement, they accomplish this by swinging their anterior ends through large circles, at the same time revolving on their axes, and then going forward in a

3 The material of Pteris multifida used in this investigation was obtained from Jamaica, B.W.I., during a visit made by the writer to that island, aided by a grant from the Bache Fund. Acknowledgment is here made to the trustees of that fund for this assistance. 
new direction. The result of this is that they experience the conditions on all sides before they continue their course in a new direction. In going in a new direction they may turn up, down, or to one side. Apparently the direction toward which they turn is that toward which the anterior end of their spiral points, but their small size made it impossible to determine this with certainty.

The movements shown in the negative and positive reactions are of the same kind as those described above. If a crystal of some salt, such as potassium nitrate, sodium chloride, etc., be placed at the edge of a drop containing sperms, a solution repellent to the sperms diffuses into the water. Sperms approaching this solution show various movements. Some of them swing their anterior ends through large circles, at the same time revolving on their axes, and then go forward as described above; such sperms often turn almost immediately from the stimulant and leave the injurious region. Most sperms, however, swing their anterior ends through smaller circles and make small turns. Such a turn may carry them into the solution, alongside of it, or away from it. If it carries them away, they usually continue this course; but if it carries them in or alongside, they turn again and again until they are headed away from the source of stimulation, and then continue forward. These sperms, therefore, usually wander here and there about the field before being headed away from the stimulant. Fig. 2 illustrates the course pursued by such sperms.

In a study of the positive responses of the sperms to the archegonium, it is immediately seen that the reactions are varied. While some sperms seem at first sight to turn directly and enter the archegonium immediately (figs. 3 and 4), others enter only after wandering about the field, occasionally going past the archegonial mouth and then turning back (figs. 5 and 6), while others pass indifferently ( fig. 7), or change their courses without entering (figs. 8-ro), or turn and leave the region (figs. $I I$ and I2). The sperms swimming in water move with great speed, but upon reaching the region in front of an open archegonium, they are slowed up by the extruded slime. A close examination of those sperms which seem to enter by turning directly to the archegonium shows that some of these slow up suddenly and swing their anterior ends through large circles, at the same time 
revolving on their axes, as previously described; they then go forward. This movement usually results in their turning toward the arche-

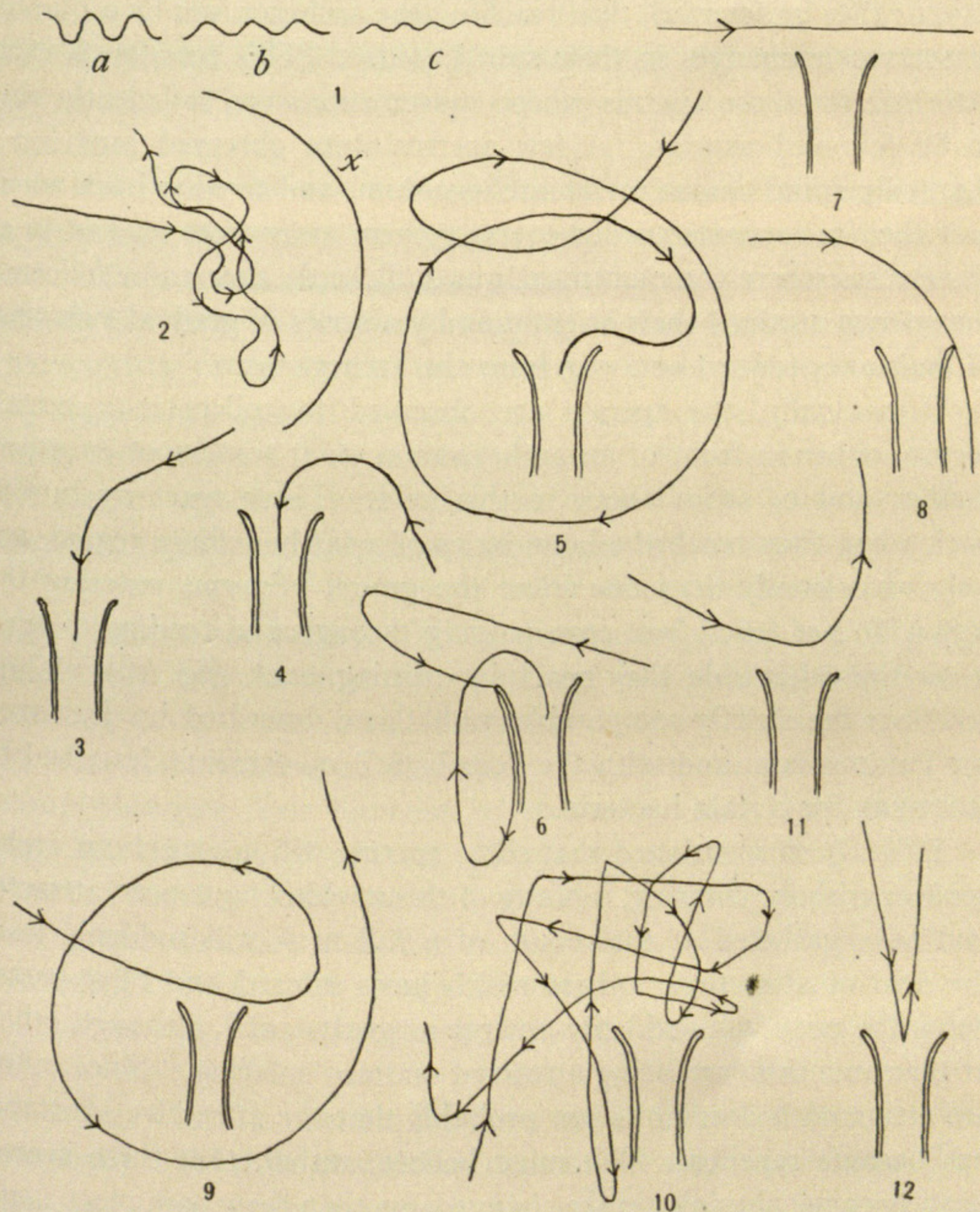

FIG. I.-Spiral courses of sperms: $a$, thick ink; $b$, thin ink; $c$, water. FIG. 2.- The position of the salt crystal is indicated by $x$. Figs. 3-1 2.-Various responses of sperms.

gonium, but not directly toward it; and their subsequent orientation and entrance into the archegonium is attained by a series of gradual swingings toward the archegonial mouth as they go forward. Most sperms, however, react less immediately and attain their orientation 
with respect to the archegonium, not by one large swing, but by a series of small swingings of their anterior ends and rotation on their axes as they go forward, thus reaching the archegonium by a number of successive changes in their spiral course. This reaction is characteristic for those sperms whose movements were sufficiently slow to be followed exactly. A few sperms were observed pursuing a markedly spiral course to the archegonium, and turning back whenever their movements tended to carry them away from it; and in all these cases where the movement was sufficiently slow to be followed, the sperms attained their orientation by a series of gradual swingings of their axes toward or away from the archegonium.

Occasionally, the sperms are observed to collect in a certain region, either in front of an archegonium or at some spot on a prothallus, and to swim about in this field. These react by turning back when they reach the boundaries of a fairly definite region, and only occasionally does one leave the group. Sperms entering this region do not react, but upon passing through and tending to leave it on the other side they react by turning back (fig. IO). These reactions are strictly comparable with those described by JENNINGS for Paramecium, and with the "apobatic" movements described by ROTHERT for certain bacteria.

It has been mentioned that some sperms will approach an archegonium without entering. Many of those which have been attracted and have gathered at the mouth of a full neck will suddenly leave the field of attraction; others which have entered and have passed down the neck will suddenly emerge at great speed, although others at the same time are being attracted and are entering. Since others are attracted it does not seem probable that the attractive substance has become repellent. We must believe, rather, that these sperms have become physiologically changed, so that they now react negatively to a substance to which they previously reacted positively.

Such emerging sperms are long and drawn out to almost a straight line; they shoot out violently from the archegonium, often forcing their way through the crowd of sperms collected at the mouth. They sometimes emerge backward, but usually come out with their anterior end foremost. They are sometimes seen to come from a great distance down the neck, apparently from the venter, and may begin 
to emerge within two minutes after the entrance has occurred. Sometimes they remain almost motionless in front of the archegonium and die after a few minutes; but often they recover and swim away. The movements of such sperms are strikingly different from normal movements. They move away quickly in almost a straight line, sometimes swerving slightly from their straight course, sometimes, upon striking an obstacle, turning slightly to one side and passing this; or they may move about irregularly, with irregular rotation on their axes. They move more in one plane than do the normal sperms, and do not show the marked swinging of their anterior ends that is characteristic of the normal movements. Often such sperms gradually regain their spiral form and their normal spiral movements, and finally swim off in a fairly normal manner. A few sperms which had left the archegonium were observed to go to the boundary of the attractive region, and then turn and reenter the archegonium.

The movements of the sperms under other conditions are exceedingly complex and varied. When sperms are placed in a very thick quince seed jelly, or when they enter far into a strong salt solution, they constantly swing their anterior ends about in large circles, at the same time rotating on their axes; they turn here and there, constantly changing their direction of movement, and frequently changing their direction of rotation. Thus one sperm in thick jelly was observed moving slowly forward in short jerks, by half-revolutions first in one direction and then in the other. Such movements are continued as long as the sperms are alive.

Sperms which have become attached to some solid body by their cilia or their vesicles perform almost every conceivable variety of movement which is possible for them under these conditions. They frequently whirl their unattached ends round and round in one direction, and then suddenly reverse this, making several or many turns in the other direction. After continuing this whirling for some time, they often swing from side to side several times and then continue whirling round and round as before. They give occasional violent jerks and swings, sometimes almost breaking themselves in two, and continue their complex movements until they die or free themselves.

Often sperms approach an open archegonium without entering, 
but remain at the mouth, uncoiling and coiling again and lashing about with their posterior ends. Since other sperms enter at the same time, it is difficult to explain these movements as being due to an injurious effect of the substance extruded from the archegonium.

On several occasions a peculiar reaction of the sperms was observed. This resembled the darting movements often seen in a swarm of gnats and will be described as the "darting reaction." Sperms exhibiting these movements collected in a fairly definite region, and showed almost constant motion, keeping one end still and swinging the other end about, or darting about in the field, here and there, with constant changes in their direction of movement. They move in every direction, sometimes approaching the archegonium, sometimes passing it, sometimes going away from it. Occasionally one proceeds in a fairly direct spiral to the boundary of the region, then turns directly back, approaches the archegonium, and resumes its darting movements. Such sperms usually do not enter the archegonium directly, but may wander in and out of the mouth. Some, however, remain in the archegonium, so that an accumulation of sperms finally occurs within the archegonial neck. A few of the sperms leave this field, but most of them remain in it until they die. Other sperms upon entering the field show the darting reactions immediately, and usually react by turning back whenever they approach the boundary of the region. This collection usually occurred in front of an open archegonium, but sometimes at other places, presumably where some of the cells of the prothallus were injured. The movements described were shown especially in the reactions of sperms of the same species and of other species toward the archegonia of Athyrium Filix-foemina, but were not shown in every case of entrance in this species, and were shown in a few cases of entrance in other species.

It now remains for us to consider which of the views stated above will best explain the movements and reactions described. We will first sum up the observed facts. It has been shown that any interference with the movements of sperms, whether by jelly, thick ink, a salt solution, or attachment to a solid particle, produces a series of complex movements; the sperms swing their anterior ends through large circles, at the same time rotating on their axes, and then go 
forward. If these movements free them from the hindrance, they resume their normal movements; but if the hindrance continues, they perform other complex movements, finally performing almost every conceivable variety of movement that is possible for them, and they continue these movements until they die or free themselves from the obstacle.

A few of the sperms showing the positive and negative reactions appear to turn directly toward or away from the stimulant. These swing their anterior ends through large circles, rotating on their axes, and then go forward in the new direction. Such movements often do not result, however, in the complete orientation of the sperms with respect to the stimulus; the final orientation is then attained by further successive swingings of their axes as they go forward. Most sperms attain their orientation by such small swingings of their axes toward or away from the stimulant as they go forward.

Occasionally sperms collect in a definite region by passing into this without reacting, and then turning back whenever they tend to leave it.

Finally, it has been shown that different sperms react differently to the same stimulus at the same time, and that the same sperm may react differently to the same stimulus at different times. In some cases these differences in reaction are due to different physiological conditions induced by different past experiences.

All these facts indicate that the reactions of fern sperms are due to the action of stimulants on the organism as a whole, and not to the direct action of a stimulant on local parts of the organism. The sperms possess a certain mechanism of reaction, and this mechanism is called into play by a change of conditions or by an interference with the normal movements. This mechanism is different in different sperms, and may be altered by different external conditions.

The strongest evidence for the direct orientation of the axes of the sperms by the stimulant is furnished by those cases in which the sperms respond by large swingings of their anterior ends and then go forward, turning fairly directly toward or away from the source of stimulation. Such cases do not prove, however, the "local action" theory of the reaction. These sperms may be regarded as having a mechanism of response by which they swing about until they are 
headed toward or away from the region of greater stimulation. They experience the conditions on all sides before continuing in their new direction, just as do those sperms which attain their orientation by many small spiral swingings in different directions. Furthermore, their new direction does not always take them directly toward or away from the source of stimulation, and their subsequent orientation is then attained by successive changes of their course as described for other sperms. Their reactions thus seem to be of the same kind as those described for other sperms. Sperms which react in this manner form a small part of those observed, and the reactions of other sperms do not accord with the "local action theory." It has been shown that some sperms collect in a region by strictly "phobotactic" responses. If we hold that the sperms described above react by "topotactic" movements, therefore, we must suppose that in both the positive and negative responses different sperms of the same species respond to the same stimulus by reactions of different natures. This is hard to believe. It seems, rather, that the sperms mentioned have their mechanisms of response called into play by the effect of the stimulant on the organism as a whole, and not by the action of the stimulant on local parts of the organism.

The reactions of fern sperms thus seem to be of the same kind as those described for protozoa.

\section{Summary}

I. Entrance of sperms into archegonia was obtained in every combination of species tried.

2. When the egg and sperm were of the same species, entrance into 97 archegonia, as shown by sections, resulted in 37 fusions; but when the egg and sperm were of different species, entrance into I 29 archegonia failed to give a single fusion. A similar result was obtained by replanting prothalli on soil after entrance had occurred.

3. The results obtained, while not disproving the existence of fern hybrids, indicate that conclusions based on the structure of the sporophyte should not be accepted without additional experimental evidence, and show that not every combination of egg and sperm can result in a fusion.

4. Sperms of one species were observed within the archegonia of another species boring against the egg. The failure of such sperms 
to enter the egg does not seem to be due to any failure of the sperm to perform its part in the process.

5. The failure of such sperms to enter the egg seems to be due either to some hindrance interposed by the egg, or to the interaction of egg and sperm. Since no means of hindrance on the part of the egg could be detected, it seems probable that this failure of the sperms to enter the eggs is due to an interaction of the egg and sperm. Such an interaction may be physical or chemical, or more probably both physical and chemical.

6. The movements of fern sperms are complex and varied. The reactions of the sperms depend on their physiological state, and this depends in part on the past experiences of the sperms.

7. Sperms have a mechanism of response which is called into action by a change of conditions or by an interference with the normal movements. In such cases they perform a series of complex movements and continue these until they die or free themselves from the stimulus.

8. Orientation of the sperms in both the positive and negative reactions is usually attained by a series of gradual swingings of their anterior ends accompanied by a rotation on their axes, and not by a sudden turning toward or away from the stimulant.

9. The observed movements and reactions seem due to the effect of the stimulant on the organism as a whole, and not to the action of different concentrations of the stimulant on local parts of the organism.

Io. The reactions of fern sperms thus seem to be of the same kind as those described for protozoa.

The author is gratefully indebted to Professor D. S. Johnson and Professor H. S. Jennings, of the Johns Hopkins University, for much helpful advice and assistance; to Mr. W. R. Maxon, U.S. National Herbarium, for the determination of the species used in this investigation, and for helpful suggestions; to Professor W. J. MoENKHaUs, Indiana University, and to Dr. D. H. Tennent, Bryn Mawr College, for permission to refer to their unpublished results; to Dr. Campbell Waters, Washington, D.C., and to Mr. W. N. Clute, Joliet, Ill., for assistance in completing the bibliography; and to $\mathrm{Mr}$. 
Amedee Hans, Stamford, Conn., for information concerning his results in the attempted crossing of ferns.

The JoHns Hopkins University

BALTIMORE

\section{LITERATURE CITED}

1. Benedict, R. C., Some fern hybrids. Science N.S. 27:542-543. 1908.

2. - New hybrids in Dryopteris. Bull. Torr. Bot. Club 36:4I-49. Igog.

3. Buller, A. H. R., Contributions to our knowledge of the physiology of the spermatozoa of ferns. Annals of Botany 14:543-582. 1900 .

4. Conard, H. S., The structure and life history of the hay-scented fern. Carnegie Inst. Washington. Igo8.

5. Copeland, E. B., Two fern monstrosities. Bot. Gazette 34:I42-I44 figs. 5. 1902.

6. Davenport, G. E., Abnormal forms and hybridity in ferns. Papers presented at Boston Meeting of Linnaean Fern Chapter. pp. I-II. I899.

7. DeVries, Hugo, Fertilization and hybridization. English translation by C. Stuart Gager. The Monist 19:514-555. I909.

8. Dowell, Philip, New ferns described as hybrids in the genus Dryopteris. Bull. Torr. Bot. Club 35: $135-140$. igo8.

9. Druery, Сh. T., Apogamic ferns. Gard. Chronicle I8: 211-212, 305-306. 1895 .

10. - A bigeneric fern hybrid. Gard. Chronicle $18: 365.1895$.

II. - Fern crossing and hybridizing. Jour. Roy. Hort. Soc. London 24: 288-297. figs. 5. 1900.

I2. FARMER, J. B., On the structure of a fern hybrid. Annals of Botany II: 533-544. pls. 23, 24. 1897 .

I3. - On the structural constituents of the nucleus, and their relation to the organization of the individual. Proc. Roy. Soc. London Bot. 79:446464. 1907 .

I4. Focke, W. O., Die Pflanzen-Mischlinge. Berlin. I880:

15. Hahne, H., Ueber Farnhybriden. Allgem. Bot. Zeitschr. 10:102-106. 1904.

16. Hans, Amedee, About abnormal ferns. Horticulture 3:611-613. figs. 4 . I906.

17. - Polystichum acrostichoides Xangulare. Fern Bull. I6:14, 15. 1908.

I8. Jennings, H. S., Behavior of the lower organisms. New York. Igo6.

19. - The interpretation of the behavior of the lower organisms. Science N.S. $27: 698-710.1908$.

20. — AND Crosby, J. H., The manner in which bacteria react to stimuli, especially chemical stimuli. Amer. Jour. Physiol. 6:31-37. I90I.

2I. Jost, J., Lectures on plant physiology. English translation by R. J. H. Gibson. Oxford. 1907. 
22. KneIP, Hans, Untersuchungen über die Chemotaxis von Bakterien. Jahrb. Wiss. Bot. 43:213-270. I906.

23. Leavitt, R. G., A vegetative mutant and the principle of homoeosis in plants. Bot. Gazette 47:30-67. figs. 19. I909.

24. Lidforss, B., Ueber die Reizbewegungen der Marchantia-Spermatozoiden. Jahrb. Wiss. Bot. 4I:65-87. I904.

25. - - Ueber die Chemotaxis der Equisetum-Spermatozoiden. Ber. Deutsch. Bot. Gesell. 23:314-3I6. 1905.

26. Lовв, J., The fertilization of the egg of the sea-urchin by the sperm of the starfish. Univ. Cal. Pub. Physiology I : 39-53. I903.

27. Lowe, E. J., Fern growing. New York. I898.

28. Luerssen, Ch., Die Farnpflanzen. Rabenhorst's Krypt. Flora. i889.

29. Martems, M., Notice sur un cas d'hybridité dans les fougères. Bull. Acad. Roy. Bruxelles 4:47-50. I837.

30. Maxon, W. R., Notes on the validity of Asplenium ebenoides as a species. Bot. Gazette 30:410-4I5. I900.

3I. - A study of certain Mexican and Guatemalan species of Polypodium. Contr. U.S. Nat. Herb. 8:271-276. pls. 61, 62. 1903.

32. Morgan, T. H., Self-fertilization induced by artificial means. Jour. Exp. Zool. I: $135^{-1} 78$. I904.

33. — - Some further experiments on self-fertilization in Ciona. Biol. Bull. 8:3r3-330. I905.

34. Mottier, D. M., Fecundation in plants. Carnegie Inst. Washington. I904.

35. Newman, H. H., On some factors governing the permeability of the egg membrane by the sperm. Biol. Bull. 9:378-387. 1905.

36. Pfeffer, W., Locomotorische Richtungsbewegungen durch chemische Reize. Unters. Bot. Inst. Tübingen $I:{ }_{36}{ }_{3}-482$. I 884 .

37. — Ueber chemotaktische Bewegungen von Bacterien, Flagellaten, und Volvocineen. Unters. Bot. Inst. Tübingen 2:582-662. I888.

38. ——, Pflanzenphysiologie $\mathbf{2}^{2}$ : 1904 .

39. RotheRt, W., Beobachtungen und Betrachtungen über tactische Reizerscheinungen. Flora 88:371-421. I90I.

40. SAdeBeck, R., Ueber Asplenium adulterimum. Verhandl. Bot. Vereins Prov. Brandenburg $\mathrm{I}_{3}: \mathrm{I}_{7} 72$; reference in SCHIMPER's Plant geography. English translation. Oxford. I903.

4I. - Ueber die generationsweisse fortgesetzen Aussaaten und Culturen der Serpentinformen der Farngattung Asplenium. Ber. Sitz. Gesell. Bot. Hamburg. Heft. 3. I887; reference in ScHIMPER's Plant geography. I903.

42. Shaw, W. R., The fertilization of Onoclea. Annals of Botany $12: 26 \mathrm{I}-285$. pl. I9. 1898 .

43. Shibata, K., Studien ueber die Chemotaxis von Isoetes-Spermatozoiden. Jahrb. Wiss. Bot. 4I:561-6ro. I905.

44. $\longrightarrow$, Studien ueber die Chemotaxis der Salvinia-Spermatozoiden. Bot. Mag. Tokyo 19:39-49. I905. 
45. Slosson, Margaret, Dryopteris cristata $\times$ marginalis. Plant World 2:4-7. pl. I. 1898 .

46. — Experiments in hybridizing ferns. Papers presented at New York Meeting of Linnaean Fern Soc. pp. I9-25. I900.

47. — The origin of Asplenium ebenoides. Bull. Torr. Bot. Club 29:487495. figs. 7. 1902.

48. Strasburger, Ed., Die Befruchtung bei den Farnkräutern. Jahrb. Wiss. Bot. 7:390-408. pls. 25, 26. 1870 .

49. Tennent, D. H., The chromosomes in cross-fertilized echinoid eggs. Biol. Bull. 15:127-134. pl. I. I907.

50. Тном, C., The process of fertilization in Aspidium and Adiantum. Trans. Acad. Sci. St. Louis 9:285-314. pls. 36-38. I899.

5I. Voegler, C., Beiträge zur Kenntniss der Reizerscheinungen. Bot. Zeit. 49:64I ff. I89I.

52. Woodburn, W. L., A remarkable case of polyspermy in ferns. Bot. GazetTe 44:227. fig. I. I907.

53. Yamanouchi, S., Spermatogenesis, oogenesis, and fertilization in Nephrodium. Bot. Gazette 45:145-175. pls. 6-8. 1908 . 


\section{$2 \mathrm{BHL}$ Biodiversity Heritage Library}

Hoyt, W D . 1910. "Physiological Aspects of Fertilization and Hybridization in Ferns." Botanical gazette 49(5), 340-370. https://doi.org/10.1086/330203.

View This Item Online: https://www.biodiversitylibrary.org/item/109578

DOI: https://doi.org/10.1086/330203

Permalink: https://www.biodiversitylibrary.org/partpdf/223411

\section{Holding Institution}

Missouri Botanical Garden, Peter H. Raven Library

\section{Sponsored by}

Missouri Botanical Garden

\section{Copyright \& Reuse}

Copyright Status: Public domain. The BHL considers that this work is no longer under copyright protection.

This document was created from content at the Biodiversity Heritage Library, the world's largest open access digital library for biodiversity literature and archives. Visit BHL at https://www.biodiversitylibrary.org. 